\title{
O conto Pai contra mãe e o filme Quanto vale ou é por quilo?: reflexões filosóficas contra a continuidade do mesmo na educação pública brasileira
}

\author{
Ildenilson Meireles Barbosa ${ }^{1}$ \\ Wanderley José Cardoso Amorim²
}

Resumo: O presente artigo tem o intuito de refletir sobre a história do ensino de filosofia no Brasil e o atual ensino de filosofia no contexto de uma escola de massa, tendo como base a Escola Estadual Doutor Odilon Loures, na cidade de Bocaiúva MG, e os alunos matriculados nas turmas do $3^{\circ}$ ano 1 e 2 do Ensino Médio da referida escola. Para a reflexão, propôs-se aos alunos encontros semanais para se refletir sobre a história da educação no Brasil e como esta, em uma escola de massa, consegue reproduzir as mesmas desigualdades históricas. Para esse intento, foram utilizados recursos didáticos literários e audiovisuais, como o conto Pai contra mãe, de Machado de Assis (1906), para tratar das relações sociais pautadas pela desigualdade no período escravista; o filme Quanto vale ou é por quilo? (2005), do diretor Sérgio Bianchi, para a análise filosófica das relações estabelecidas na sociedade atual como mantenedora das desigualdades históricas do tempo da escravidão, mas com uma roupagem diferente. Esta pesquisa busca mostrar que o ensino de filosofia pode pensar os problemas históricos brasileiros através de reflexões produzidas no âmbito nacional, sendo elas literárias ou cinematográficas, e que mudanças significativas podem ocorrer no âmbito menor da sala de aula e na relação estabelecida entre professor e aluno.

Palavras-chave: Ensino de filosofia. Escola Pública. Desigualdades. Política e Educação. Resistência.

\section{The tale Father against mother and the movie How much it costs or is it for kilo?: filosofical reflections against the continuity of the same in Brazil's public education}

\begin{abstract}
This article has as purpouse reflect about the history of philosophy teaching in Brazil and the current philosophy teaching Mass education and based on the Doutor Odilon Loures State School, in the city of Bocaiuva, Minas Gerais State, And third grade high school students of classes 1 and 2 of the mentioned school. In order to think It over, weekly meetings have been proposed for the students to think about history of the education in Brazil and how, in a mass education school, it could reproduce the same historical inequality. For this, literary and audiovisual resources have been used,

\footnotetext{
1 Doutor em filosofia. Professor dos Programa de Pós-Graduação em história (PPGH), Filosofia (Prof.Filo) e Desenvolvimeto Social (PPGDS) da Universidade Estadual de Montes Claros, campus Montes Claros. Minas Gerais, Brasil. E-mail: meirelesildenilson@gmail.com

Orcid: https://orcid.org/0000-0002-0528-727X.

${ }^{2}$ Mestre em filosofia. Professor de Filosofia da Rede Estadual de Educação de Minas Gerais. Minas Gerais, Brasil. E-mail: wandboc@yahoo.com.br

Orcid: https://orcid.org/0000-0002-4170-0404.
} 
as the narrative Pai contra mãe, by Machado de Assis (1906) to treat the social relationships matter guided by the inequality on enslaving period; the film Quanto vale ou é por quilo? (2005), from the diretor Sérgio Bianchi, for the philosophic analysis of established relations on nowadays society as a maintaining of historical inequality from slavery, but with a different approach. This research pursuits to show that the teaching of philosophy could think through the historical brazilian problems by the produced reflections on the nacional sphere, being literary or cinematographic, and the signicant changes may occur on an small context of a classroom and the stablished relationship made between teacher and student.

Keywords: Philosophy teaching. Public School. Inequalities. Politics and Education. Resistance.

\section{El cuento Pai contra Mãe y la película Quanto vale ou é por kilo?: Reflexiones filosóficas contra la continuidad del mismo en la educación pública brasileña}

Resumen: Este artículo tiene como objetivo reflexionar sobre la historia de la enseñanza de la filosofía en Brasil y la enseñanza actual de la filosofía en el contexto de una escuela de masas, con base en la Escuela Estatal Doutor Odilon Loures, en la ciudad de Bocaiúva - MG, y los estudiantes matriculados en las clases de 3er año 1 y 2 de la Escuela Secundaria de esa escuela. Para la reflexión, se propuso a los alumnos reuniones semanales para reflexionar sobre la historia de la educación en Brasil y cómo ésta, en una escuela de masas, puede reproducir las mismas desigualdades históricas. Para ello, se utilizaron recursos didácticos literarios y audiovisuales, como el cuento Pai contra Mãe, de Machado de Assis (1906), para tratar las relaciones sociales basadas en la desigualdad durante la época de la esclavitud; la película Quanto vale ou é por quilo? (2005), del director Sérgio Bianchi, para el análisis filosófico de las relaciones que se establecen en la sociedad actual como mantenedora de las desigualdades históricas desde la época de la esclavitud, pero con un disfraz diferente. Esta investigación busca mostrar que la enseñanza de la filosofía puede pensar los problemas históricos brasileños a través de reflexiones producidas en el ámbito nacional, sean literarias o cinematográficas, y que pueden ocurrir cambios significativos en el ámbito más pequeño del aula y en la relación que se establece entre docente y estudiante.

Palabras clave: Enseñanza de la filosofía. Escuela pública. Desigualdades. Política y educación. Resistencia.

\section{O conto Pai contra mãe e o cidadão contra a escola pública}

\footnotetext{
"Seria uma atitude muito ingênua esperar que as classes dominantes desenvolvessem uma forma de educação que permitissem às classes dominadas perceberem as injustiças sociais de forma crítica" - Paulo Freire
}

As reflexões que se seguem são frutos de uma intervenção filosófica realizada no âmbito da Escola Estadual Doutor Odilon Loures, da cidade de Bocaiúva, norte de 
Minas Gerais, no ano de 2019 e com os alunos do $3^{\circ}$ ano 1 e 2 do Ensino Médio. Para tal usamos como recursos didáticos o conto Pai contra mãe, escrito por Machado de Assis em 1906 e o filme Quanto vale ou é por quilo? (2005), do diretor Sérgio Bianchi, ambas as obras nacionais.

A escolha de recursos didáticos brasileiros é para reforçar a noção diante dos alunos de que temos possibilidade de pensar o Brasil e nossas relações sociais a partir de ideias e obras brasileiras. Por mais que o conto Pai contra a Mãe do escritor brasileiro Machado de Assis esteja distante do nosso tempo e não fale especificamente sobre educação e filosofia, ele servirá de base para um melhor entendimento do filme Quanto vale ou é por quilo? e para a compreensão de cunho filosófico e político das relações e atores da escola pública de massa na contemporaneidade brasileira.

Machado de Assis escreveu o conto Pai contra a mãe dezoito anos após a abolição da escravatura no Brasil, mais precisamente no ano de 1906. Ao iniciar o conto, Machado nos descreve em um pequeno relato como os donos dos escravos usavam instrumentos para castigar os escravizados, como o ferro no pescoço, ferros e correntes nos pés e a máscara de folha-de-flandres - que retirava dos escravos o vício da bebida ao ser colocada no rosto, pois só tinham alguns buracos na direção dos olhos para o escravo enxergar, alguns furos na direção do nariz para respirar e era fechada atrás da cabeça por um cadeado, tapando assim a boca do escravo. O próprio Machado de Assis reconhece que era grotesca a máscara, mas, ironicamente, reconhece que a ordem humana e social nem sempre se alcança sem o grotesco e alguma vez o cruel.

Diante dessa realidade, muitos escravos fugiam, o que fazia com que os seus senhores dispensassem forças para recapturá-los. Um cartaz descritivo era pregado em locais públicos com a descrição das características físicas, nome e roupas que o escravizado usava, juntamente com o valor da recompensa para quem o capturasse.

Depois de descrever a relação entre os senhores e os seus escravos, Machado traz a história de Cândido Neves, um homem que por não conseguir se fixar em nenhum emprego, torna-se um caçador de escravos fugitivos, uma atividade comum para a época. Cândido logo se casa com a jovem Clara, uma moça órfã que vive com a Tia Mônica, a quem ela ajuda com os trabalhos de costureira. Clara logo engravida e diante da escassez de escravizados fugidios, a família enfrenta grande dificuldade financeira. $\mathrm{O}$ proprietário da casa onde moravam exigia receber os meses de aluguel atrasados, logo, 
não foi possível ficar mais naquele lugar e eles foram morar de favor. A criança nasce e tia Mônica convence o casal a levar o bebê para Roda dos Enjeitados.

Para evitar que a criança morresse de fome, Cândido Neves decide levá-la a conhecida Roda dos Enjeitados. Porém, ao passar pela chamada Rua da farmácia ele avista uma mulher com as mesmas características de uma escravizada fugitiva, de nome Arminda. No mesmo instante ele deixa o filho com o farmacêutico e vai atrás daquela mulher. Ao chamá-la, Arminda vira em direção a Cândido e já é tarde demais. Ao ser pega com o uso da força por Cândido Neves, Arminda revela que está grávida, suplica, chora, pede que a soltasse pelo amor de Deus, mas isso não impede que o caçador a leve ao seu dono. Muitas pessoas que estão nas portas das lojas e saem às janelas assustados com os gritos da escrava, nada fazem, pois sabem o que está acontecendo.

Cândido Neves, ao entregar Arminda ao seu senhor, recebe a sua recompensa de cem mil-réis, enquanto a escravizada Arminda, diante do seu senhor e de Cândido Neves em posse da sua recompensa, aborta o bebê que esperava. Entre os gemidos da mãe e gestos de desespero do senhor, Cândido Neves viu todo esse espetáculo. Sem querer conhecer as consequências do desastre, pega seu filho com o farmacêutico e volta para casa. Agora o pai Cândido Neves poderá cuidar do seu filho à custa da captura e consequente aborto de Arminda que nem sequer conheceu o seu filho.

É possível observar que Machado faz uma dura crítica à sociedade brasileira daquele período, denunciando a condição desumana e a exploração vivenciada não apenas pelos negros escravizados, mas também pelos brancos que apesar de não serem escravizados viviam em situação de extrema pobreza.

Fotocópias do conto Pai contra mãe foram repassadas aos alunos para que fosse feita a leitura em casa. No primeiro encontro do projeto de intervenção fizemos a leitura de cada parágrafo. Um dos primeiros questionamentos feitos acerca da descrição feita por Machado de Assis em relação aos instrumentos de tortura, destacando-se a já mencionada máscara feita de Folha de Flandres e a relação entre os senhores e seus escravos é se algum aluno tinha dúvidas se a escravidão realmente aconteceu no Brasil e que se os escravizados eram forçados a viver uma vida degradante desde o momento que eram trazidos ao Brasil pelos portugueses através do tráfico negreiro.

Todos os alunos responderam que não tinham dúvidas, pelos relatos históricos de que os negros eram explorados contra a sua vontade e que existem vários indícios e 
instrumentos que eram usados como castigos e punições aos negros nas chamadas cidades históricas de Minas Gerais. Depois de algumas intervenções defendendo a tese de que realmente tivemos um sistema cruel de exploração dos negros no Brasil, foram apresentados aos alunos parte da entrevista dada pelo então candidato à presidência Jair Messias Bolsonaro à emissora de televisão Cultura, no programa intitulado "Roda viva”, no dia 30 de julho de 2018. Numa resposta durante a entrevista, o presidenciável do PSL negou que o Brasil tenha uma dívida histórica com a população negra por causa da escravidão. Ele afirmou que "o português nem pisava na África e eram os próprios negros que entregavam os escravos" ${ }^{3}$. Além de negar uma dívida histórica, cogitou diminuir as cotas raciais ${ }^{4}$ para os negros.

$\mathrm{Na}$ época da entrevista de Bolsonaro, vários historiadores foram contrários e emitiram notas demonstrando que o presidenciável estava equivocado ${ }^{5}$, mas em nenhum momento o presidenciável negou que estivesse equivocado em relação ao seu posicionamento.

\footnotetext{
${ }^{3}$ É importante acompanhar o vídeo com parte da entrevista onde Jair Bolsonaro faz a declaração sobre a escravidão e em relação ao acesso à educação superior através da lei das cotas. Disponível em: https://www.youtube.com/watch?v=vtbXWVEW188. Acesso em 16/02/2019.

${ }^{4}$ No Brasil, o sistema de cotas tornou-se conhecido em meados dos anos 2000, inicialmente pela Universidade do Estado do Rio de Janeiro (UERJ), que foi a primeira universidade do país a criar um sistema de cotas em vestibulares para cursos de graduação por meio de uma lei estadual que estabelecia $50 \%$ das vagas do processo seletivo para alunos egressos de escolas públicas cariocas. Depois da UERJ, foi a vez da Universidade de Brasília (UnB) implantar uma política de ações afirmativas para negros em seu vestibular de 2004, em meio a muita discussão e dúvidas dos próprios vestibulandos. A instituição foi a primeira no Brasil a utilizar o sistema de cotas raciais. De lá para cá, apesar de não serem muitas até então, outras universidades também foram aderindo às cotas em seus certames, destinando reserva de vagas não só para negros, como também para indígenas, pardos e membros de comunidades quilombolas - por meio de cotas raciais - e também para deficientes e estudantes de baixa renda oriundos de escolas públicas - o que chamamos de cotas sociais. Ou seja, em nosso país, teoricamente o sistema de cotas não beneficia exclusivamente negros. $\mathrm{O}$ funcionamento do sistema de cotas nas instituições pode ser definido de acordo com as suas próprias políticas e regulamentos, tendo hoje variados modelos pelo Brasil. O que se tem geralmente é a reserva de uma parcela das vagas para aqueles candidatos que estudaram no ensino médio da rede pública de ensino. Essa medida fortaleceu-se ainda mais com a aprovação da lei $\mathrm{n}^{\circ} 12.711$, de agosto de 2012, conhecida também como Lei de Cotas. Por meio dela, as instituições de ensino superior federais tinham até agosto de 2016 para destinarem metade de suas vagas nos processos seletivos para estudantes oriundos de escolas públicas. A distribuição dessas vagas também leva em conta critérios raciais e sociais. Disponível em: https://vestibular.mundoeducacao.bol.uol.com.br/cotas/historia-sistemacotas-no-brasil.htm. (Acesso em 17/02/19). De acordo com Joaquim Barbosa, ex-ministro e único negro do STF até a atualidade: "Essas medidas visam a combater não somente manifestações flagrantes de discriminação, mas a discriminação de fato, que é a absolutamente enraizada na sociedade e, de tão enraizada, as pessoas não a percebem."

5 "Negar que exista uma dívida histórica (com a escravidão) é simplesmente querer apagar a História, esquecer ou fingir que não existiu um passado que nos liga a uma escravização por 400 anos e ainda é presente na sociedade atual de diferentes maneiras. Uma delas é o próprio racismo" - afirmou Iamara da Silva Viana, doutora em História e professora da Pontifícia Universidade Católica do Rio de Janeiro (PUC-Rio).
} 
Dialogar filosoficamente com um parágrafo de um conto do Machado de Assis do ano de 1906, fazendo uma relação com textos jornalísticos e uma visão ideológica do Presidente do Brasil em 2019, fundamentando ideias e pontos de vista através de textos de historiadores e de leis criadas diante da realidade vivida, desenvolve-se no aluno a possibilidade de criar suas próprias ideias em relação a determinados assuntos que estão presentes no seu dia a dia. Não são poucos os casos de postagens racistas na internet atualmente, pessoas que são contrárias às políticas de cotas que se apossam de ideias como a do Presidente Bolsonaro para dizer que a cor da pele não deve ser pré-requisito para o acesso ao ensino superior, quando na verdade as cotas escondem problemas sociais bem mais amplos que o mero fato de ter a cor da pele negra.

Durante as reflexões acerca da situação do negro no Brasil e os equívocos relacionados em relação às cotas raciais, levamos o problema para a área educacional de uma escola de massa. Por séculos vivemos no Brasil um sistema socialmente excludente para o acesso à educação. Não eram necessárias leis, mas socialmente os brancos e ricos tiveram acesso à educação e a maioria da população negra e pobre foram excluídas. Reflexões acerca de textos literários, preconceitos, relatos históricos e políticas públicas de acesso à educação devem ser feitas constantemente, principalmente pelos mais jovens que são matriculados na escola de massa, para que meras opiniões não se transformem em verdades estabelecidas para as novas gerações. O sistema de cotas para os negros carentes e para os alunos carentes de escola pública (quase uma redundância dizer aluno de escola pública e carente, pois estudar em um sistema de ensino público brasileiro já é um atestado de carência), não exclui o branco rico, pois eles nunca foram excluídos do acesso à educação, pelo contrário, foram sempre privilegiados; definitivamente, as cotas incluem, possibilitam e oportunizam o acesso de seres humanos à educação.

A continuidade do conto justifica o próprio título Pai contra mãe, pois apesar de pertencerem a classes sociais diferentes, a negra Arminda, uma escrava fugitiva, e o Cândido Neves, branco e livre, ambos são vítimas das mesmas desigualdades sociais. A única diferença entre Cândido e Arminda é que a condição de escravizada fugitiva de Arminda servirá de sobrevivência para Cândido e sua família, o que é materializado na perseguição e consequente aborto de Arminda.

Partindo da lógica machadiana, metaforicamente, o nosso sistema educacional parece padecer desses dualismos sociais: aluno contra escola, aluno contra professor e 
pais contra professores. A mesma violência provocada pelo Pai, representada por Cândido, contra a Mãe, representada pela escrava Arminda, é a mesma violência que o sistema escolar sofre atualmente dos próprios agentes que fazem parte dele.

O aluno contra escola: Atualmente é visível a violência provocada pelo aluno contra o patrimônio material da escola em que estuda. São recorrentes as cadeiras quebradas, portas, paredes rabiscadas com xingamentos, banheiros com pias e vasos quebrados. Na Escola Estadual Doutor Odilon Loures, não se pode deixar papel higiênico nos banheiros porque em poucos minutos alguém retira o papel do seu lugar, deixa molhar ou deposita nos vasos sanitários, entupindo-os de forma intencional.

Durante essas observações, muitos alunos questionaram que em outros espaços públicos acontece a mesma coisa. Geralmente, espaços públicos são depredados, banheiros públicos são quebrados. Esses comportamentos sociais, em parte, podem ser explicados pela falta de cuidado com a coisa pública vivida na idade escolar e que é transplantada e revivida como natural na vida adulta.

As relações conflituosas entre alunos e escola se refletem no desejo de fuga desse espaço. Os prédios escolares geralmente são cercados por muros altos, com arames ou cacos de vidro. A entrada do estabelecimento é estreita, geralmente existe apenas uma entrada para número grande de alunos. As portas das salas são estreitas e as janelas, quando não são pequenas, são colocadas grades. Logo, os alunos fizeram a relação do espaço escolar com o espaço prisional. É como se eles, os alunos, estivessem cumprindo uma pena escolar de 10,11, 12 anos e para alguns até mais quando ficam retidos por não alcançarem o comportamento e notas esperados, a diferença é que podem ir as suas casas, mas devem voltar todos os dias para frequentar aquele espaço da escola vigiados constantemente por diretores, supervisores, professores e horários preestabelecidos.

Muitas dessas medidas de "segurança" são justificadas pelo cuidado e zelo com o patrimônio público e o receio de sofrer violência externa como roubos e invasões. Mas também representam o desejo de controlar e manter os alunos dentro de um espaço determinado e evitar possíveis "fugas" desse espaço de controle. O aluno que tenta saltar os muros da escola ou fugir é considerado um mau aluno e, consequentemente, 
deve ser identificado e punido. ${ }^{6}$ No entanto, são medidas paliativas, uma vez que, como escreveram Antônio Moreira e Vera Candau:

O que caracteriza o universo escolar é a relação entre as culturas, relação essa atravessada por tensões e conflitos. Isso se acentua quando as culturas crítica, acadêmica, social e institucional, profundamente articuladas, tornam-se hegemônicas e tendem a ser absolutizadas em detrimento da cultura experiencial, que, por sua vez, possui profundas raízes socioculturais. Em vez de preservar uma tradição monocultural, a escola está sendo chamada a lidar com a pluralidade de culturas, reconhecer os diferentes sujeitos socioculturais presentes em seu contexto, abrir espaços para a manifestação e valorização das diferenças. É essa, a nosso ver, a questão hoje posta. A escola sempre teve dificuldade em lidar com a pluralidade e a diferença. Tende a silenciá-las e neutralizá-las. Sentese mais confortável com a homogeneização e a padronização. No entanto, abrir espaços para a diversidade, a diferença, e para o cruzamento de culturas constitui o grande desafio que está chamada a enfrentar (MOREIRA e CANDAU, 2003, p. 161).

Sendo assim, nas relações estabelecidas entre o aluno e a escola é como se a última tivesse o papel de estabelecer um espaço fictício de relações, falas teatralmente estabelecidas de comportamentos esperados e desejáveis durante algumas horas na vida do aluno. É como se a espontaneidade, as diferenças e as pluralidades de ideias cotidianas vividas pelos alunos em suas vidas cotidianas tivessem que ser dissolvidas, camufladas, suspensas em nome de um objetivo maior que não é bem compreendido pelo aluno e que responde a este espaço com alguma espécie de violência.

Aluno contra professor: a violência tanto física, verbal, moral e ética que atualmente é estabelecida na relação entre alunos e professores ou vice-versa, em grande parte representa o fracasso da nossa educação pública e gratuita. Historicamente a autoridade dos professores foi estabelecida através da violência física advinda da própria relação familiar. A escola era vista como uma extensão da casa, tanto que era e ainda é comum algumas professoras serem chamadas de "tias". A violência que os professores aplicavam contra os alunos que não apresentavam um comportamento

\footnotetext{
${ }^{6}$ O deputado Eduardo Bolsonaro (PSL-SP) quer alterar a Lei de Diretrizes e Bases (LDB) da educação para nela incluir a expulsão imediata e a recusa de matrícula em instituições de ensino para alunos que tenham sido condenados administrativamente ou judicialmente em casos de depredação de patrimônio público. No Projeto de Lei (PL) 1.192/2019, Eduardo Bolsonaro prevê que "serão desvinculados compulsoriamente e terão recusadas as matrículas nos estabelecimentos oficiais de ensino, os discentes que forem condenados administrativamente ou judicialmente em casos de depredação do patrimônio público". Disponível em: https://www.revistaforum.com.br/eduardo-bolsonaro-quer-expulsao-e-recusade-matricula-para-alunos-que-depredarem-patrimonio/. Acesso em: 04/03/2019.
} 
esperado durante as aulas eram idênticos aos castigos que os senhores de escravo davam aos seus escravos que descumpriam ordens, tinham algum vício ou tentavam fugir. Não são poucos os relatos dos mais velhos dos castigos que eram dados pelos seus professores como ordenar que o aluno se ajoelhasse no milho, palmatórias, ficar no canto da sala de costas para o restante da turma com um chapéu conhecido como chapéu de burro. Como Machado de Assis relatou no conto Pai contra a mãe que a ordem humana e social nem sempre se alcança sem o grotesco e alguma vez o cruel, o que tornam os relatos mais grotescos contados pelos mais velhos é perceber certo saudosismo e prazer ao relatar as torturas vividas no passado dentro das escolas. É como se o escravo fosse grato por quem o açoitou no tronco.

Essas relações foram consideradas normais, em grande parte, porque os professores pertenciam a classes de pessoas mais ricas, pois eram professores porque conseguiam ter acesso a uma educação que a maioria da população não tinha acesso e as famílias acreditavam que a forma violenta de educar era necessária para garantir o aprendizado.

Atualmente, essa relação inverteu-se. O aluno não aceita mais a "violência" como forma educativa e, além disso, converte a não aceitação em violência de caráter físico, moral e de todas as ordens. Os alunos e seus núcleos familiares já não são os mesmos de outros tempos, mas também o professor já não é fruto de uma classe elitizada, a maioria dos professores das escolas públicas também estudou em escolas públicas e com essa mesma realidade. A triste constatação é que ambos, professores e alunos estão no mesmo barco e afundam juntos.

Pais contra professores: o distanciamento dos pais e responsáveis em relação à vida escolar dos seus filhos é algo assustador. Na Escola Estadual Doutor Odilon Loures, os alunos do Ensino Médio têm aulas de filosofia desde o $1^{\circ}$ ano, então, o mínimo que o aluno terá que conviver com a disciplina de filosofia e com o seu professor são 3 anos. Nesses 3 anos não foi estabelecido nenhum contato com os pais ou responsáveis pelos 45 alunos que compõem cada turma que participou do projeto. Apesar das reuniões acontecerem bimestralmente para repasse de resultados, os pais dos alunos não comparecem à escola, é como se o aluno fosse abandonado em sua vida estudantil pela família quando alcança o Ensino Médio. É como se o adolescente frequentasse todos os dias um determinado local, convivesse com um número de pessoas e se encontrasse por um dia na semana com um indivíduo chamado professor e 
os pais nunca tivessem a curiosidade de saber quem são essas pessoas, quem é esse ser que se chama professor, que encontra o seu filho toda semana e ensina uma disciplina chamada filosofia.

Por outro lado, esse distanciamento é interrompido quando acontece alguma coisa grave e a direção convida o pai à escola; fora isso, o aluno se forma e o pais nem sequer sabem quem foi "aquele cara" que seu filho encontrava todas as semanas durante 3 anos na escola.

Esse distanciamento tende a ficar mais conflituoso com projetos como o "Escola sem partido" 7 e as acusações que são feitas aos professores pelos políticos profissionais. Como esses discursos ganham mais publicidade na mídia e em ambientes virtuais que a prática real dos professores no cotidiano escolar, o professores são vistos com desconfiança, mas sempre de longe.

O professor Fernando Penna, em seu artigo o discurso reacionário de defesa de uma "escola sem partido" alerta para os perigos de projetos como o Escola sem partido e suas finalidades camufladas por uma preocupação com a educação pública:

O nome "escola sem partido" foi muito bem escolhido para explorar o enorme desprezo que a maioria dos brasileiros sente em relação aos políticos profissionais. A expressão coloca-nos diante de uma

\footnotetext{
${ }^{7}$ O projeto de lei conhecido como "Escola Sem Partido" (PL 7180/14) propõe acrescentar tópicos à Lei de Diretrizes e Bases da Educação Nacional (LDB), de 1996, e dispor sobre a conduta dos professores dentro de sala de aula. Segundo o projeto, o artigo $3^{\circ}$ da Lei de Diretrizes e Bases da Educação Nacional será acrescido do seguinte inciso: "Respeito às crenças religiosas e às convicções morais, filosóficas e políticas dos alunos, de seus pais ou responsáveis, tendo os valores de ordem familiar precedência sobre a educação escolar nos aspectos relacionados à educação moral, sexual e religiosa". Também haverá o acréscimo, no mesmo artigo, do parágrafo a seguir: "A educação não desenvolverá políticas de ensino, nem adotará currículo escolar, disciplinas obrigatórias, nem mesmo de forma complementar ou facultativa, que tendam a aplicar a ideologia de gênero, o termo 'gênero' ou 'orientação sexual'”. O projeto de lei prevê, ainda, que seja afixado um cartaz, em todas as salas de aula do país, com uma lista de "seis deveres do professor":

1 - "O professor não se aproveitará da audiência cativa dos alunos para promover os seus próprios interesses, opiniões, concepções ou preferências ideológicas, religiosas, morais, políticas e partidárias".

2 - "Não favorecerá nem prejudicará ou constrangerá os alunos em razão de suas convicções políticas, ideológicas, morais ou religiosas, ou da falta delas".

3 - "Não fará propaganda político-partidária em sala de aula nem incitará seus alunos a participar de manifestações, atos públicos e passeatas".

4 - "Ao tratar de questões políticas, socioculturais e econômicas, apresentará aos alunos, de forma justa — isto é, com a mesma profundidade e seriedade —, as principais versões, teorias, opiniões e perspectivas concorrentes a respeito da matéria".

5 - "Respeitará o direito dos pais dos alunos a que seus filhos recebam a educação religiosa e moral que esteja de acordo com as suas próprias conviç̧ões".

6 - "Não permitirá que os direitos assegurados nos itens anteriores sejam violados pela ação de estudantes ou terceiros, dentro da sala de aula". Disponível em: https://www.programaescolasempartido.org/ Acesso: $03 / 09 / 2018$
} 
dicotomia: ou você é a favor de uma escola sem partido ou de uma escola com partido. Uma pessoa que não conheça a atuação do movimento ou o teor dos projetos tende a declarar a sua adesão, só porque o termo já mobiliza o desprezo comum pela política partidária. O grande problema é que não é disso que trata o projeto: sob a desculpa de combater a propaganda partidária em sala de aula, ele na verdade pretende erradicar a dimensão educacional da escola. Sou contra o uso do espaço da sala de aula para fazer propaganda partidária, mas isso não faz de mim um defensor do projeto. Para o movimento, os professores não são educadores, mas burocratas que devem apenas transmitir conteúdos definidos por lei, sem mobilizar valores e sem falar da realidade a qual a escola está inserida. (PENNA, 2018, p. 110).

A constatação do professor Fernando Penna se deve, em parte, ao distanciamento dos alunos, familiares e sociedade em geral do âmbito escolar e a falta de conhecimento da história da educação no Brasil, acabando, assim, por reproduzir os mesmos resultados históricos. Alunos que terminam o Ensino Médio nas escolas públicas brasileiras, em sua maioria, não conseguem produzir mudanças significativas socialmente, intelectualmente ou politicamente, e repetem, ainda que escolarizados, os mesmos comportamentos dos seus pais que não tiveram acesso à educação. Os reflexos da formação intelectual destituída de uma reflexão histórica é a reprodução de preconceitos históricos de toda ordem e a constituição de uma sociedade que ao lidar com as diferenças relutam para a manutenção do mesmo. Nesse contexto, muitos pais são contra os próprios professores dos filhos sem nem sequer conhecê-los, mesmo tendo essa possibilidade de ir ao encontro do professor na escola.

É inegável o fato que a escola pública não está livre da corrupção, pois ela também pode ser usada ou instrumentalizada para práticas equivocadas e de corrupção:

Não negamos essa corrupção, mas argumentamos que as sempre presentes tentativas de cooptação e de corrupção ocorrem justamente para domar o potencial distinto e radical que é exclusivo do escolar em si mesmo. Desde a sua criação nas cidades-estados gregas, o tempo escolar tem sido o tempo em que o "capital" (conhecimentos, habilidades, cultura) é expropriado, liberado como um "bem comum" para o uso público, existindo, portanto, independente de talento, habilidade ou renda. E essa expropriação radical, ou "tornar público", é difícil de ser tolerada por todos os que procuram proteger a propriedade. Estes podem ser a elite cultural ou a geração mais velha, que trata a sociedade como sua propriedade e, desse modo, assume a posse do futuro dos jovens. (MASSCHELEIN, 2018, p. 15). 
Os discursos conservadores travestidos de uma preocupação com o futuro dos jovens e, consequentemente, da nação, camuflam um desejo de classes privilegiadas e de políticos que representam essas classes, de inviabilizar a escola pública. Na visão dos conservadores e críticos da escola pública qualquer exceção se transforma em regra geral para uma crítica avassaladora dos sistemas de ensino gratuitos, assim fazendo com que a escola pública e gratuita seja sempre alvo de reformas, mas reformas que visam, na verdade, frear a liberdade e moldar o tempo livre dos alunos e professores.

O que levou o pai (Cândido) a perseguir e entregar a mãe (Arminda) para o seu senhor no conto Pai contra mãe foi a falta de capacidade de reflexão. Cândido Neves não conseguiu enxergar que Arminda era a transfiguração feminina da sua própria condição humana. Assim é o ensino na escola pública de massa, os agentes envolvidos nela, por falta de reflexão, não conseguem enxergar que a escola são os alunos; no aluno existe o professor e vice-versa, e os pais podem contribuir para a melhoria das condições da escola e das relações estabelecidas entre professores, alunos e escola, pois apesar das diferenças hierárquicas no âmbito escolar, fazem parte de uma mesma realidade social, são cidadãos advindos das camadas mais pobres.

Ao final da reflexão acerca do conto, das relações sociais vividas entre senhores e escravos, constatamos que no âmbito de uma escola de massa estabelecemos relações muito parecidas com o período escravagista vivido no Brasil, com roupagens diferentes, mas reproduzindo o mesmo.

Cândido Neves é a representação social do professor atual. Desvalorizado no exercício profissional, financeiramente e socialmente, que se vê obrigado a ser um cumpridor de ordens de um sistema educacional que cada dia mais requer que o professor seja apenas agente punidor do Estado, mantendo a ordem escolar. Cumprir esse fluxo contínuo é necessário para sua sobrevivência fora dos muros da escola, onde têm suas contas para pagar, têm os seus filhos, que vale salientar, em sua maioria, não estudam nas escolas públicas e gratuitas, mas em colégios particulares, pagos a duras penas, pois os professores não desejam que os seus filhos tenham a educação ruim do próprio estabelecimento de ensino em que ele leciona.

Arminda é o reflexo do nosso aluno na escola, quando fazendo uso da sua liberdade de não querer ficar fechado em uma sala de aula, cumprindo regras, deveres e tarefas indesejáveis, tenta fugir dessa lógica e é punido exemplarmente, expulso ou 
recriminado pelo seu professor ou algum agente que recebe uma "recompensa" do Estado para exercer esse papel exemplarmente.

O senhor de escravos representa aqueles que, assim como no conto, só aparecem para financiar essas relações e manter esses jogos de desigualdade através de leis, decretos e declarações públicas através de redes sociais como facebook, Instagran e Twitter. ${ }^{8}$ Essas declarações com o intuito de mudanças radicais na educação tendem a levar mais conflito nas relações entre alunos, professores, escola e sociedade, mantendo assim uma relação historicamente desigual, onde o político nunca é atingido diretamente e nem a sobrevivência dos seus familiares.

\section{Quanto vale ou é por quilo? A repetição histórica entre opressores e oprimidos}

Quanto vale ou é por quilo? é um filme brasileiro do ano de 2005, dirigido por Sérgio Bianchi. ${ }^{9}$ Parte do filme é inspirado no conto Pai contra mãe, de Machado de Assis, e na obra do historiador Nireu Cavalcanti. O longa é uma mistura de ficção e documentário, tanto que durante o filme são mostrados documentos históricos do Arquivo Nacional e pesquisas acerca da realidade brasileira para fundamentar algumas reflexões.

O filme é uma adaptação do conto Pai contra mãe para mostrar que relações sociais presentes nos séculos XVIII e XIX ainda persistem no século XXI no Brasil. Esse tema é explorado através de reminiscências mostrando como a escravidão era movida pela exploração de seres humanos para manutenção e lucro dos senhores brancos e de como essa exploração continua no século XXI de forma ressignificada. A exploração dos mais pobres é camuflada no filme através da caridade oferecida principalmente pelas ONGs (Organizações não Governamentais sem fins lucrativos), que no filme são tratadas como verdadeiras empresas de fachada para sonegar impostos e desviar verbas públicas.

\footnotetext{
${ }^{8} \mathrm{O}$ atual presidente da República Jair Messias Bolsonaro e seus Filhos se comunicam com os cidadãos brasileiros através das suas contas no Twitter. Pronunciamentos acerca de medidas a serem tomadas e posicionamentos políticos. O presidente Bolsonaro recentemente postou sobre educação: "Há algo de muito errado acontecendo: as prioridades a serem ensinadas e os recursos aplicados. Para investigar isso, o Ministério da Educação junto com o Ministério da Justiça, Polícia Federal, Advocacia e Controladoria Geral da União, criaram a Lava-Jato da Educação"; "Dados iniciais revelam indícios muito fortes que a máquina está sendo usada para manutenção de algo que não interessa ao Brasil. Sabemos que isto pode acarretar greves e movimentos coordenados prejudicando o brasileiro. Em breve muito mais informações para o bem de nosso país". Disponível em: https://twitter.com/jairbolsonaro. Acesso no dia 04/03/2019.

9 Sérgio Luís Bianchi (Ponta Grossa, 25 de novembro de 1945) é um cineasta brasileiro que tem como reputação ser um contestador, implacável crítico do Brasil, de nossas mazelas, de nossos costumes e pecados.
} 
A segunda etapa do projeto de intervenção na Escola Estadual Doutor Odilon Loures foi assistir ao filme e propor uma ressignificação a partir de uma visão social do Brasil atual, principalmente em relação aos últimos acontecimentos políticos e as intervenções políticas propostas para educação na atualidade. Antes de iniciar o filme, foi deixada uma pergunta para os alunos responderem na terceira etapa do encontro: VOCÊ E SEU GRUPO FAMILIAR SE IDENTIFICAM COM O OPRESSOR OU COM O OPRIMIDO?

Apesar de parecer uma pergunta óbvia de ser respondida no contexto de uma escola pública de massa, onde os alunos advêm de classes sociais menos favorecidas, logo somos levados a pensar que todos vão se identificar com os oprimidos. Mas a questão não é tão simples quando se observa que se identificar como oprimido não significa o mesmo que lutar ou buscar formas de diminuir a opressão, pelo contrário, muitas ideias e visões sobre a realidade brasileira defendida pelos alunos representam muito mais o opressor que o oprimido.

Neste ponto, nos aproximamos do pensamento de Paulo Freire ${ }^{10}$, principalmente das reflexões do seu livro Pedagogia do oprimido, escrito no ano de 1968, durante o exílio do autor no Chile. Lembrar-se das ideias de Paulo Freire e da sua biografia no contexto político e educacional que vivemos atualmente é uma tarefa filosófica de primeira grandeza. Não só pela lembrança da sua grandiosidade como educador e dos prêmios e títulos que recebeu em todo o mundo, mas por uma mentalidade que cresceu atualmente no Brasil de fazer uma ligação entre o fracasso da educação pública

\footnotetext{
${ }^{10}$ Preocupado com o grande número de adultos analfabetos na área rural dos estados nordestinos, que formavam um grande número de excluídos, Paulo Freire desenvolveu um método de alfabetização baseado no vocabulário do cotidiano e da realidade dos alunos. As palavras eram discutidas e colocadas no contexto social do indivíduo. Por exemplo: o agricultor aprendia as palavras, cana, enxada, terra, colheita, fogo etc. e os alunos eram levados a pensar nas questões sociais relacionadas ao seu trabalho. A partir das palavras base, ia se construindo novas palavras e ampliando o vocabulário. A iniciativa do educador foi aplicada pela primeira vez, em 1962, na cidade de Angicos no sertão do Rio Grande do Norte, quando foram alfabetizados 300 trabalhadores da agricultura. O projeto ficou conhecido como "Quarenta horas de Angicos". Os fazendeiros da região chamavam o processo educativo de "praga comunista". Com o golpe militar de 1964, Paulo Freire foi acusado de agitador e levado para a prisão onde passou 70 dias, e em seguida se exilou no Chile. Durante cinco anos desenvolveu trabalhos em programas de educação de adultos no Instituto Chileno para a Reforma Agrária. Em 1969, Paulo Freire lecionou na Universidade de Harvard. Durante dez anos, foi consultor especial do Departamento de Educação do Conselho Municipal das Igrejas, em Genebra, na Suíça. Viajou por vários países do Terceiro Mundo dando consultoria educacional. Por seu trabalho na área educacional, Paulo Freire foi reconhecido mundialmente. É o brasileiro com mais títulos de Doutor Honoris Causa de diversas universidades, são 41, ao todo, entre elas, Harvard, Cambridge e Oxford.

Paulo Freire faleceu em São Paulo, no dia 2 de maio de 1997. Disponível em: https://www.ebiografia.com/paulo_freire/. Acesso no dia 23/02/19.
} 
brasileira ao método Paulo Freire, considerado marxista e doutrinador. ${ }^{11}$ Tornou-se comum atribuir certos adjetivos pejorativos a qualquer pessoa que levanta a voz contra as desigualdades ou tenha ligação com a esquerda no Brasil.

A própria proposta de um projeto de intervenção na área de filosofia em uma escola pública que se propõe refletir a respeito das desigualdades sociais no Brasil e buscar formas de amenizá-las através da educação já se torna ofensivo para alguns, e citar Paulo Freire para fundamentá-lo pode desencadear ações e atitudes de críticas negativas.

Mas essa luta dialética entre senhores e escravos deve ser enfrentada para sua superação, que só é possível pela conscientização e liberdade daquele que é oprimido, pois a lógica dos opressores é de continuidade da opressão.

O próprio Paulo Freire tinha essa consciência de que o oprimido tem a capacidade de dar fim à opressão:

Quem, melhor que os oprimidos, se encontrará preparado para entender o significado terrível de uma sociedade opressora? Quem sentirá, melhor que eles, os efeitos da opressão? Quem, mais que eles, para ir compreendendo a necessidade da libertação? Libertação a que não chegará pelo acaso, mas pela práxis de sua busca; pelo conhecimento e reconhecimento da necessidade de lutar por ela. Luta que, pela finalidade que lhe derem os oprimidos, será um ato de amor, com o qual se oporão ao desamor contido na violência dos opressores, até mesmo quando esta se revista da falsa generosidade referida (FREIRE, 1987, p. 31).

A citação acima do livro Pedagogia do oprimido reforça a necessidade do filme Quanto vale ou é por quilo? enquanto recurso didático para que o aluno compreenda a importância de se ter um pensamento crítico sobre a realidade brasileira para que velhos preconceitos e ideias destituídas de conhecimento acerca de nós mesmos não venham a perpetuar as nossas mazelas.

A primeira cena do filme já retrata a justiça brasileira como uma defensora dos opressores. É uma contradição dizer que a justiça defende o opressor, pois o próprio termo opressor já carrega o signo da injustiça e de causar prejuízo a alguém ou a um

\footnotetext{
${ }^{11}$ Nas manifestações contra o governo Dilma em 2015, uma faixa escrita "Chega de Doutrinação Marxista, Basta de Paulo Freire" foi vista nas ruas. Em caixa de comentários do Facebook, os ataques também são comuns.
} 
grupo de pessoas em específico, mas a distância entre os conceitos e a realidade em uma sociedade pautada pela desigualdade são recorrentes.

A voz do narrador cita o caso da escravizada alforriada Joana, que tem seus escravos alforriados roubados da sua fazenda pelos capitães do mato de um senhor branco chamado Manuel Fernandes. Acreditando na justiça e na força coletiva, Joana e populares vão à casa do senhor branco para reaver os seus escravos, não obtendo êxito, recorre à justiça com documentos que comprovam que ela foi roubada, mas a sentença dos juízes é em seu desfavor afirmando que ela foi contra a lei vigente do código penal do Vice-Reinado que condena qualquer tipo de comportamento que perturbe a paz social. Joana é condenada por perturbação da ordem residencial e por ofender o Senhor Manuel Fernandes com ofensas morais e raciais. A ré foi recolhida a prisão e teve que pagar 15 mil réis para ter sua liberdade de volta.

O mais trágico é que esse relato não é ficção, foi extraído do Arquivo Nacional de 1799, Rio de Janeiro, no Vice-Reinado, caixa 490. Duas questões se levantam diante da constatação da injustiça sofrida pela alforriada Joana: a Justiça no Brasil é realmente justa? Todos são tratados da mesma forma pela Justiça brasileira, pobre e ricos?

A resposta em coro dos alunos é que a justiça brasileira é desigual e sempre defende os mais ricos, mesmo eles estando errados. Interessante como é um assunto que incomoda os alunos, pois muitos fizeram intervenção oral dando exemplos de vários casos em que pessoas que cometeram crimes graves no Brasil e tinham boas condições financeiras foram soltas ou sequer foram punidas.

É uma constatação dos alunos de 16 a 18 anos acerca da justiça atual do Brasil. Por mais que seja um senso comum, parece que temos uma Justiça que defende interesses de uma elite dominante desde o Período Colonial. É o que constata Rubens Casara (2018) ${ }^{12}$ em seu artigo intitulado Precisamos falar da "direita jurídica”, contido no livro $O$ ódio como política - a reinvenção das direitas no Brasil:

No Brasil, os atores jurídicos estão lançados em uma tradição autoritária que não sofreu solução de continuidade após a redemocratização formal do país com a Constituição de 1988. A naturalização da desigualdade e da hierarquização entre as pessoas, um dos legados da escravidão, por exemplo, continuam a ser percebidos na sociedade brasileira e, em consequência, também

\footnotetext{
12 Rubens R.R. Casara é doutor em direito, mestre em ciências penais e juiz de direito do Tribunal de Justiça (RJ). É autor de Estado pós-democrático (2017) e Processo Penal do espetáculo (2018).
} 
influenciam a produção das normas. Mas, não é só. No Brasil, os atores jurídicos que serviam aos governos autoritários continuaram, após a redemocratização formal do país, a atuar no sistema de justiça com os mesmos valores e a mesma crença no uso abusivo da força que condicionavam a aplicação do direito no período de exceção (CASARA, citado em GALLEGO, 2018, p.74).

A função da Filosofia e a prática docente não deve se limitar a reproduzir na escola os mesmos debates genéricos e pautados pela violência das redes sociais e da vida social, mas fazer com que cada aluno por si mesmo faça uma análise mais crítica e aprofundada da realidade brasileira. Ademais, esses debates acalorados trazem a sensação que o aluno está desenvolvendo um pensamento crítico (livre de qualquer coerção ideológica partidária ou midiática) quando, na verdade, é apenas a reprodução de discursos prontos e ideias propagadas na sua vida fora da escola. Isso pode gerar a sensação de que a filosofia é um "bate-papo" nos moldes da vida privada e provocar rejeição ao próprio pensamento filosófico.

Neste intuito, o papel da intervenção filosófica não é repassar ideias prontas, afinal

A escola seria o lugar para oportunizar a tomada de consciência quanto às relações de poder e de controle presentes nas instituições e na sociedade. Esta, a condição fundamental para um processo pedagógico que tenha como alvo a emancipação. Torna-se imprescindível, assim, discutir o modo como as relações de poder e dominação vão sendo institucionalizadas, bem como as possibilidades de se implementar resistência a elas (SILVA, 2008, p. 89).

No decorrer do filme, o diretor Sérgio Bianchi entra no universo do conto Pai contra mãe. Os nomes dos personagens são os mesmos do conto: Arminda, Cândido Neves (apelidado de Candinho), Clara (mulher de Candinho) e tia Mônica. A diferença é que como o filme representa relações sociais do século XXI, já não temos a presença do branco Senhor de escravos. Mas a ironia é que os senhores de escravos são substituídos por ONGs e por grupos de pessoas que, aparentemente, se preocupam com as desigualdades sociais e com os mais carentes.

Essas pessoas e ONGs fazem propagandas televisivas representando crianças, em sua maioria negras, em estado de degradação social e criam campanhas de doações de alimentos e de dinheiro para que sejam revestidos na ajuda aos mais necessitados. A sobrevivência dessas ONGs e das pessoas que trabalham nelas só são garantidos através da corrupção, da instrumentalização de outros seres humanos e dos desvios de dinheiro 
que deveriam beneficiar os mais pobres. Em tese, a exploração humana dos escravos nos séculos XVIII e XIX é transformada em caridade, disfarçada pelo marketing social em preocupação com os mais necessitados, mas possui apenas um intuito: o lucro.

Ao intercalar cenas das relações entre escravos e brancos no período escravocrata, onde os brancos sempre lucram financeiramente na exploração do trabalho e no desejo de liberdade dos escravos, e cenas retratando o século XXI, o filme demonstra que a evolução da exploração alcança também os pobres: é como se o desejo do oprimido fosse alcançar a condição de opressor.

Isso fica bem claro numa cena em que a personagem da Tia Mônica que trabalha distribuindo sopas para moradores de rua para a ONG de Noêmia, começa a refletir como seria se ela mesma tivesse sua ONG. Ao retratar os pensamentos de Tia Mônica, o filme mostra de forma magistral como funciona o inconsciente de quem se dispõe a ajudar os mais pobres. Tia Mônica se vê em um programa de televisão intitulado "vencendo com o social" e contando como se tornou uma pessoa bem sucedida ao se deparar com a pobreza e miséria diante dos seus olhos. Abandonando tudo, dedicou sua vida a ajudar os mais pobres, era uma vocação (um chamado) para ajudar as pessoas. Interessante notar que ao se imaginar bem sucedida administrando sua própria associação, Tia Mônica constrói seu teatro mental colocando sua patroa Noêmia como sua empregada e seus colegas de trabalho como pessoas carentes ajudadas por ela. $\mathrm{O}$ "sonho acordado" de Tia Mônica é interrompido pelo chamado da sua patroa Noêmia.

Nessa ótica, o sonho do oprimido é ser opressor, mas esse sonho é fruto de um egoísmo individual e não cessa a opressão. Paulo Freire em Pedagogia do oprimido sintetiza a construção psicológica da personagem da Tia Mônica, ao escrever que

A violência dos opressores, que os faz também desumanizados, não instaura uma outra vocação - a do ser menos. Como distorção do ser mais, o ser menos leva os oprimidos, cedo ou tarde, a lutar contra o que os fez menos. E esta luta somente tem sentido quando os oprimidos, ao buscarem recuperar sua humanidade, que é uma forma de cria-la, não se sentem idealistamente opressores, nem se tornam, de fato, opressores dos opressores, mas restauradores da humanidade em ambos. E aí está a grande tarefa humanista e histórica dos oprimidos libertar-se a si e aos opressores. Estes, que oprimem, exploram e violentam, em razão de seu poder, não podem ter, neste poder, a força da libertação dos oprimidos nem de si mesmos (FREIRE, 1987, p.30). 
Neste momento do filme, encerramos o segundo encontro de intervenção filosófica e foi levantada a seguinte questão para os alunos: Desejamos acabar com a opressão ou o nosso desejo é ser opressor de oprimidos?

\section{Resistência menor para uma mudança cidadã maior}

No dia 14 de março de 2018, uma mulher negra, pobre, homossexual, porém, livre, ocupante do cargo político de vereadora, eleita democraticamente pela vontade coletiva, foi assassinada juntamente com o seu motorista branco, casado, pai de um filho de 1 ano de idade. Os dois foram assassinados na cidade brasileira mais conhecida no mundo, o Rio de Janeiro. Até o momento não sabemos quem foram os capitães do mato que executaram o crime e nem os senhores que mandaram executar. Só nos resta criar mais um herói morto.

A terceira etapa do projeto de intervenção tem como intuito refletir sobre as possibilidades de resistência diante da manutenção histórica da exploração de seres humanos de classes menos privilegiadas por seres humanos de classes sociais mais privilegiadas, tendo o filme Quanto vale ou é por quilo? como guia.

A mediação, realizada primeiramente com o conto machadiano e posteriormente com o filme busca alcançar os objetivos que para a professora Lídia Maria Rodrigo são a finalidade da didática em filosofia:

- Criar mediações pedagógicas que facilitem o processo de aprendizagem.

- Promover a transição para a construção da capacidade de pensar por conta própria, de modo que o estudante consiga gradativamente dispensar mediações heterônimas, construindo, ele próprio, suas mediações com a filosofia (RODRIGO, 2009, p.26).

Assim como no conto de Machado de Assis, a personagem Arminda é representada no filme como uma negra, mas diferente da escravizada, a Arminda do século XXI é "livre". Livre entre aspas, porque percebe que ela e outros negros e pessoas carentes são instrumentalizados pelos donos da empresa em que ela trabalha para, através da corrupção, desviar dinheiro público que era para ser investido em obras assistenciais. 
A Arminda do século XXI é a representação do desejo de liberdade da escrava Arminda do período escravocrata. O desejo de liberdade da Arminda do filme de Sérgio Bianchi é aflorado por uma atitude filosófica: o espanto.

Esse espanto acontece quando os donos da empresa em que ela trabalha vão à periferia inaugurar uma sala com computadores que foram doados à comunidade. A cena da inauguração é espantosa, porque retrata várias crianças atirando bolinhas de papel no ar, totalmente descontrolados e alheios ao que está acontecendo. Assim que a faixa da inauguração é cortada várias crianças gritando observam que os computadores nem sequer ligam e em um ato de rebeldia alguns computadores são jogados no chão pelos alunos. No meio dessa confusão, Arminda tenta controlar as crianças, espantada com o que está acontecendo.

O espanto maior se dá quando um amigo revela para a Arminda que a caridade da doação dos computadores para a comunidade faz parte de um esquema de superfaturamento. A verba era maior, mas foram comprados computadores de qualidade mais baixa para desvio do dinheiro. $\mathrm{O}$ amigo de Arminda apresenta documentos que comprovam a fraude entre a empresa que ela trabalha (Stiner) e os políticos. O amigo de Arminda ainda comenta:

Arminda, são as oligarquias, elas se encontram, fazem novas alianças, combinam velhos esquemas, esse pessoal deita e rola e depois ainda ganham a eleição, fica tudo sempre nas mesmas mãos. E pra gente sobra o quê? Esse papel chato de ficar fazendo denúncia... É a direita faturando na permanência da miséria.

Ao final, Arminda não se sente bem, pois observa que está em um restaurante onde a elite se reúne para montar seus projetos sociais e superfaturar ou sonegar impostos das suas empresas.

"A filosofia nasce do espanto" (Aristóteles), a resistência também. A filosofia é uma forma de resistir ao que é dado como costumeiro e uma ação para compreendê-la ou modificá-la de alguma forma. A atitude de Arminda será filosófica.

Antes das ações práticas de Arminda, o filme mostra dados acerca das ONGs e associações no Brasil. O total de dinheiro arrecado e movimentado pelas ONGs no Brasil, o número de empregos que elas geram a cada criança carente, o número de crianças que moram na rua. Os dados apresentados no filme assustam qualquer telespectador, todos ficam espantados. 
Arminda, no decorrer do filme, observa que em todas as pessoas carentes ou em situação de rua, existe o sofrimento que também é dela. Começa a se enxergar em uma senhora idosa que carrega um carrinho com suas roupas acompanhada de uma criança. A cena do filme mostra Arminda no lugar da idosa empurrando o carrinho de madeira, mas com a máscara de folha-de-flandres no rosto. Cada vez mais, Arminda vai ficando sufocada pelas desigualdades sociais diante dos seus olhos, por outro lado, desperta a consciência que deve fazer algo para mudá-la.

Arminda, buscando justiça, procura Ricardo Pedrosa, um dos sócios da Stiner e responsável pelo superfaturamento dos computadores "doados" à comunidade, para reaver o dinheiro que foi desviado. Mas a lógica de Ricardo Pedrosa é a mesma lógica de um sistema escravista. Não existe nada de errado em explorar seres humanos, quando outros seres humanos vivem dessa exploração. E, além disso, Ricardo Pedrosa faz com que Arminda se sinta ameaçada por sua própria sobrevivência e a sobrevivência dos outros, ao dizer que ao tentar ser heroína, Arminda coloca em risco o seu emprego e de outras pessoas que sobrevivem dos projetos sociais.

Assim como no conto de Machado, os caminhos de Arminda e Cândido se cruzam no filme. Arminda, mulher negra, grávida e querendo justiça contra os desvios e superfaturamento de projetos sociais realizados pela empresa Stiner e políticos corruptos; Cândido, casado com Clara que também está grávida, desempregado, morando de favor com Tia Mônica que se encontra endividada e com o aluguel do imóvel onde moram atrasado. Cândido, diariamente, sofre pressões da Tia Mônica pela falta de dinheiro em casa para pagar o aluguel. Sua esposa Clara, mesmo com as dificuldades, idealiza uma vida de artista e de ostentação, pois passa os dias em casa olhando fotos de artistas em revistas de moda e se imaginando naquela situação. ${ }^{13}$ Pressionado por todos os lados e sem emprego, a única solução encontrada por Candinho é se tornar um matador de aluguel.

A necessidade ética, de justiça e liberdade de Arminda se cruza com as necessidades financeiras de Candinho. Ricardo Pedrosa, com receio das denúncias contrata os serviços do matador de aluguel Candinho. O filme não mostra, mas, com certeza, Candinho recebe uma foto com características físicas de Arminda e o seu

\footnotetext{
${ }^{13}$ Não podemos afirmar com absoluta certeza, mas os desejos de Clara de ter uma vida de artista podem ser os mesmos desejos que perpassam na cabeça de um jovem que curte o "funk ostentação". O desejo de ser rico, famoso, ostentando dinheiro e mulheres. É a fábrica de sonhos que a mídia cria e que são incorporados nos comportamentos no cotidiano.
} 
endereço, assim como os Capitães do mato buscavam anúncios de escravas fugidas. Candinho encontra a negra rebelde e executa o serviço contratado pelo senhor branco. Garante, assim, o pagamento do aluguel, a vida boa que sua esposa tanto sonhava e a satisfação de Tia Mônica. Esse é o final do filme Quanto vale ou é por quilo?!

Diante desse final, a sensação é que não adianta lutar contra as desigualdades neste país. Lutar contra a exploração dos mais pobres pelos ricos é sentença de morte. Direitos iguais para todos, sejam negros, pobres, brancos, índios, homossexuais, qualquer luta contra a desigualdade não passará de "mimimi". ${ }^{14}$

Melhorias na educação pública através de greves, protestos e reinvindicações são pedir para apanhar da polícia e vai continuar do mesmo jeito. Negra, mulher e pobre na política denunciando políticos homens, brancos e corruptos é pedir para morrer.

Não existe uma saída? Ou isso acontecerá por sucessivas vezes em um eterno retorno do mesmo?

A saída é a resistência!

Dos vários sentidos que a palavra possui, resistência é o ato, ação ou efeito de resistir, de não ceder nem sucumbir; aptidão para suportar dificuldades (fadiga, fome, esforço); qualidade de um corpo que reage contra a ação de outro corpo. E Sérgio Bianchi nos proporciona outro final, a esperança que não sabemos onde vai dar.

A cena é refeita, Arminda prestes a ser assassinada convence Cândido a não matá-la e juntos fazerem justiça buscando, mesmo que de forma violenta, o dinheiro que pertence a eles mesmos. É como se o filme deixasse que cada um dos telespectadores escolhesse o seu final e, através da imaginação e da reflexão, pensasse em outros finais para a história do filme, para a nossa história de cada dia de Armindas, Candinhos,

\footnotetext{
14 Já caiu no linguajar popular, mas principalmente nos debates acirrados nas redes sociais. Você certamente leu ou ouviu a expressão "mimimi". O termo que remete ao choro é normalmente usado na tentativa de diminuir a manifestação de ideias de uma pessoa. O que poucos lembram é de onde surgiu o famoso "mimimi". Se você pensou que foi na internet, se enganou. Foi na televisão, mais especificamente no politicamente incorreto desenho animado "Fudêncio e Seus Amigos", que era transmitido pela MTV Brasil. O protagonista, Fudêncio, se comunicava apenas na língua do "mimimi" para provocar o reclamão e irritado Conrado. Foi aí que a única fala do personagem virou uma expressão para tirar uma onda com qualquer queixa. Só que, atualmente, na opinião dos criadores do "Fudêncio", Marco Pavão e Thiago Moraes, a expressão está sendo usada de forma errada e acabou se tornando uma arma para detonar qualquer manifestação. Disponível em: https://www.revistaforum.com.br/criadores-do-mimimi-criticammau-uso-do-termo/. Acesso dia: 16/02/2019.
} 
Mônicas, Chicos Mendes ${ }^{15}$, Dorothy Stang ${ }^{16}$, Amarildos $^{17}$, Marielles Franco ${ }^{18}$ da nossa história mais recente

\section{Considerações Finais}

Ao usar como recursos didáticos o conto Pai contra mãe, de Machado de Assis e o filme Quanto vale ou é por quilo? todos produtos nacionais e tratando, em diferentes contextos, a realidade do Brasil, podemos observar que a instrumentalização dos menos favorecidos como um fator histórico se reproduz também dentro da escola e nas relações das pessoas que estão envolvidas no processo de aprendizagem.

Nos dois recursos didáticos utilizados ficou bem claro para os alunos a importância de vigiar os mais pobres e as punições necessárias quando as regras estabelecidas forem quebradas. Com a escola pública de massa não é diferente:

15 Na noite de 22 de dezembro de 1988, o ecologista Chico Mendes, presidente do Sindicato dos Trabalhadores Rurais de Xapuri, no Acre, foi morto a tiros de espingarda, no quintal de sua casa, por Darcy Alves da Silva, a mando de seu pai, o fazendeiro Darly Alves da Silva. Chico Mendes havia sido condecorado pela ONU no ano anterior, por sua luta em defesa do meio ambiente. O ecologista, que ajudara a organizar o trabalho e a resistência dos seringueiros, foi o fundador da primeira reserva extrativista do Brasil, 40 mil hectares de exploração conservacionista, em São Luiz do Remanso, situado a 80 quilômetros de Rio Branco, capital do Acre. Sua morte repercutiu no mundo inteiro, onde era conhecido como o "herói da floresta", tendo sido o único brasileiro a participar, em 1988, de uma reunião de 500 ecologistas de todo o mundo na ONU, em Washington. Apesar desse histórico de lutas e de ser reconhecido mundialmente como uma autoridade em defesa do meio ambiente, o atual Ministro do Meio Ambiente, Ricardo Salles, do governo de Jair Messias Bolsonaro, em entrevista para o programa "Roda viva" da TV Cultura afirmou não conhecer Chico Mendes e que já ouviu falar coisas negativas e positivas ao seu respeito. Ao final do programa diz ser irrelevante saber quem é Chico Mendes e que não faria diferença no momento. Disponível em: https://www.youtube.com/watch?v=IBzKuyqrcAA. Acesso no dia 20/02/2019. Essas afirmações e tantas outras de ministros, secretários, simpatizantes, filhos do presidente e do próprio Jair Messias Bolsonaro são uma forma de desconsiderar lutas históricas que não convém ideologicamente ao governo, principalmente, quando de forma irresponsável tentam passar a ideia que qualquer movimento de luta por direitos das minorias, de igualdade social ou por justiça pelas mortes de pessoas que tiveram ou tem ligação com esses movimentos possam ser condenados por estarem ligados a interesses partidários da esquerda. Logo, podemos considerar ou constatar que qualquer cidadão ou grupo que defenda o meio ambiente, minorias, educação de qualidade no atual contexto político, corre o risco de ser assassinado e ter sua morte justificada por pertencer a um pensamento político e partidário de esquerda. Vivemos em uma democracia ainda?

${ }^{16}$ Numa estrada de terra de difícil acesso a 53 quilômetros de Anapu (PA), no dia 12 de fevereiro de 2005, a missionária católica Dorothy Mae Stang foi assassinada com sete tiros, por defender os sem-terra. Os latifundiários Vitalmiro Bastos de Moura e Regivaldo Pereira Galvão são apontados como os principais mandantes do crime.

${ }^{17}$ Em 14 de julho de 2013, o pedreiro Amarildo Dias de Souza, morador da Favela da Rocinha, no Rio de Janeiro, foi levado a Unidade de Polícia Pacificadora (UPP) local para prestar esclarecimentos. A família registrou o desaparecimento dele dois dias depois. Em outubro, após três meses de investigações, o Ministério Público denunciou 25 policiais militares pela morte de Amarildo. Treze tiveram prisão decretada. O julgamento começou em fevereiro de 2014 e ainda não foi concluído. O corpo de Amarildo até hoje não foi encontrado.

18 Marielle Franco é mulher, negra, mãe e cria da favela da Maré. Socióloga com mestrado em Administração Pública. Foi eleita Vereadora da Câmara do Rio de Janeiro pelo PSOL, com 46.502 votos. Foi também Presidente da Comissão da Mulher da Câmara. No dia 14/03/2018 foi assassinada em um atentado ao carro onde estava. 13 Tiros atingiram o veículo, matando também o motorista Anderson Pedro Gomes. 
Foi sorte da escola, ao longo da história, ter escapado da censura definitiva por juiz ou júri ou de ter sido privada de seu direito de existir. Ou, mais propriamente, durante uma grande parte da história, os esforços para punir as transgressões da escola foram correcionais: a escola era algo a ser constantemente melhorado e reformado. Era tolerada, desde que se submetesse a programas de ajuste ou se dedicasse ao serviço de um conjunto de ideais fixos (políticos e religiosos) e projetos já prontos (a construção da nação, as missões civilizadoras) (MASSCHELEIN, 2018, p. 9).

O contexto apresentado por Jan Masschelein em seu livro Em defesa da escola: uma questão pública é o mesmo em que vivemos nas escolas públicas brasileiras. Quando a escola se torna democrática e camadas sociais começam a ter acesso a lugares, serviços, condições intelectuais e sociais antes exclusivas às camadas mais privilegiadas, a educação maior administrada por políticos e grupos sociais que se enxergam como classes privilegiadas atacam a escola e esse ataque tende a atribuir à educação escolar o rótulo de geradora de problemas sociais de todas as ordens.

Infelizmente, falar de políticas públicas para a educação, de igualdade social através de programas de distribuição de renda, igualdades de gênero, raça, religiosidade dentro das escolas públicas ou em qualquer lugar público é ser taxado de comunista, petista (uma alusão ao Partido dos trabalhadores), doutrinador e corre o risco de ser denunciado pelos partidários do programa "Escola sem partido" por defender partidos políticos em sala de aula.

Tratar o ensino de filosofia em uma escola de massa, ou seja onde for, sem levar em consideração esses problemas é negar a própria filosofia. Fingir que as aulas de filosofia não estão sendo afetadas por ideologias políticas e religiosas, continuar seguindo programas curriculares escritos por essa educação maior e ceder aos desejos privados de pais e alunos que querem impedir professores e outros alunos de pronunciarem pensamentos e ideias que não convém ao atual governo de extremadireita e a princípios religiosos é contribuir para a reprodução do mesmo.

Devido a esses e tantos outros que acontecem dentro e fora da escola, que acabam influenciando o pensar filosófico em sala de aula, é que esse trabalho se apresenta como uma resistência ao eterno retorno do mesmo do ensino de filosofia no Brasil. O ensino de filosofia dentro de uma escola de massa, com 40 horas/aula anuais não pode se dar ao luxo de reproduzir o pensamento de filósofos de outras 
nacionalidades e culturas que trataram de problemas específicos do seu tempo. Por mais que exista correspondência e uma universalidade em alguns conceitos filosóficos, tentar adaptar ou transplantar esses conceitos distantes no tempo para a sala de aula é um trabalho que demanda tempo maior e condições culturais e políticas favoráveis, o que não é o nosso caso. A resistência é urgente.

Durante as intervenções tomamos cuidado para que as reflexões filosóficas acerca do conto e dos dois filmes não recriassem a polarização política vivida na sociedade entre "esquerda" e "direita". Durante as discussões e exemplos, fatos históricos e opiniões contrárias foram apresentados e sempre buscamos um consenso sobre o que seria melhor para a coletividade, independente de posicionamentos políticos pessoais. Por mais que as ideias recebam rótulos políticos e religiosos, através do diálogo e concatenação de ideias, ao pensar a sociedade brasileira e sua formação histórica, fomos chegando às conclusões acerca do que está acontecendo atualmente. Um ato político em sua essência, sem se apresentar como partidário, mas que futuramente pode apresentar frutos partidários, pois os alunos já participam da vida política através do voto e logo serão cidadãos com o poder do voto fora dos muros da escola pública.

\section{Referências}

ASPIS, Renata Lima; GALLO, Sílvio. Ensinar Filosofia: Um livro para professores. São Paulo: Atta Mídia e Educação, 2009.

BRASIL, Ministério da Educação e Cultura do. Diretrizes e Bases da Educação Nacional - LEI 9394-96. LEI N ${ }^{\circ}$ 9.394, DE 20 DE DEZEMBRO DE 1996 (DOU 23.12.96).

CARMINATI, Celso. O ensino de filosofia no II grau: do seu afastamento ao movimento pela sua reintrodução. A Sociedade de Estudos e Atividades Filosóficas/SEAF. Mestrado em Educação. Florianópolis, SC: CCE-UFSC, 1997.

CARTOLANO, Maria Teresa Penteado. Filosofia no ensino de $2^{\circ}$ Grau. São Paulo: Cortez: Autores Associados, 1985.

CARRILHO, Manuel Maria. Razão e transmissão da Filosofia. Lisboa: Imprensa Nacional Casa da moeda, 1987.

CASARA, Rubens. Precisamos falar da "direita jurídica". In.: GALLEGO, Esther Solano (org.). O ódio como política: a reinvenção da direita no Brasil. São Paulo: Boitempo, 2018. 
FREIRE, Paulo. Pedagogia da Autonomia: saberes necessários à prática educativa. Rio de Janeiro: Paz e Terra, 2000.

FREIRE, Paulo, Pedagogia do Oprimido. Editora Paz e Terra - 29a edição - 1987.

MASSCHELEIN, Jan; SIMONS, Maarten. Em defesa da escola: uma questão pública. 2 ed. Belo Horizonte: Autêntica, 2018.

REBOUL, Olivier. A doutrinação. São Paulo: Nacional/Edusp, 1980.

MOREIRA, Antonio Flavio Barbosa; CANDAU, Vera Maria. Educação escolar e cultura(s): construindo caminhos. In: Revista Brasileira de Educação. n. 23, mai/ago, 2003.

RODRIGO, Lidia Maria. Filosofia em sala de aula: teoria e prática para o Ensino Médio. Campinas, SP: Autores Associados, 2009.

SILVA, Mônica Ribeiro da. Teoria curricular e teoria crítica da sociedade: elementos para (re)pensar a escola. In: InterMeio - Revista do Programa de Pós-Graduação em Educação, Campo Grande, MS, v. 14, n. 28, p. 80-91, jul.-dez./2008.

\section{Recursos Didáticos:}

ASSIS, Machado de. Pai contra Mãe. Disponível em: http://www.dominiopublico.gov.br/download/texto/bv000245.pdf. Acesso em: 4 set. 2018.

Quanto vale ou é por quilo?. Direção: Sérgio Bianchi. Produção: Paulo Galvão. Roteiro: Sérgio Bianchi, Eduardo Benaim, Newton Canitto. [S.I]: RIOFILME, Petrobras e Agravo Produções, 2005.

\section{Sites e Periódicos online}

Biografia de Paulo Freire. Disponível em: https://www.ebiografia.com/paulo_freire/. Acesso em: 23 fev. 2019.

Criadores do "mimimi" criticam mau uso do termo. Disponível em: https://www.revistaforum.com.br/criadores-do-mimimi-criticam-mau-uso-do-termo/.

Acesso em: 16 fev. 2019.

Eduardo Bolsonaro quer expulsão e recusa de matrícula para alunos que depedrarem patrimônio. Disponível em: https://www.revistaforum.com.br/eduardo-bolsonaro-querexpulsao-e-recusa-de-matricula-para-alunos-que-depredarem-patrimonio/. Acesso em: 04 abr. 2019. 
Escárnio: "Chico Mendes é irrelevante", diz Ministro do Meio Ambiente no Roda Viva. Disponível em: https://www.youtube.com/watch?v=IBzKuyqrcAA. Acesso em: 20 fev. 2019.

História do sistema de cotas no Brasil. Disponível em: https://vestibular.mundoeducacao.bol.uol.com.br/cotas/historia-sistema-cotas-nobrasil.htm. Acesso em: 17 fev. 2019.

Izalci apoia gestão compartilhada em escolas públicas. Disponível em: https://www12.senado.leg.br/noticias/materias/2019/02/12/izalci-apoia-gestaocompartilhada-em-escolas-publicas. Acesso em: 15 fev. 2019.

Jair Bolsonaro no Roda Viva, culpa os negros pela escravidão no passado. Disponível em: https://www.youtube.com/watch?v=vtbXWVEW188. Acesso em: 16 fev. 2019.

Michel Onfray. Disponível em: http://www.filosofia.com.br/bio_popup.php?id=69. Acesso em: 10 fev. 2019.

Novo Ensino Médio: perguntas e respostas. Disponível em: http://portal.mec.gov.br/component/content/article?id=40361\#nem_01. Acesso em: 03 set. 2018.

Por uma lei contra o abuso da liberdade de ensinar. Disponível em: https://www.programaescolasempartido.org/. Acesso em: 03 set. 2018.

Sérgio Moro: veja quem é o juiz que ganhou projeção nacional com a Lava Jato.

Disponível em: https://g1.globo.com/pr/parana/noticia/2018/11/01/sergio-moro-vejaquem-e-o-juiz-que-ganhou-projecao-nacional-com-a-lava-jato.ghtml. Acesso em: 24 fev. 2019. 